\title{
Milk production responses to different strategies for feeding supplements to grazing dairy cows
}

\author{
M. J. Auldist, ${ }^{1}$ L. C. Marett, J. S. Greenwood, M. M. Wright, M. Hannah, J. L. Jacobs, and W. J. Wales \\ Agriculture Research Division, Department of Economic Development, Jobs, Transport and Resources, Ellinbank VIC 3821, Australia
}

\begin{abstract}
Milk production responses of grazing cows offered supplements in different ways were measured. Holstein-Friesian cows, averaging $45 \mathrm{~d}$ in milk, were allocated into 8 groups of 24 , with 2 groups randomly assigned to each of 4 feeding strategies. These were control: cows grazed a restricted allowance of perennial ryegrass pasture supplemented with milled wheat grain fed in the milking parlor and alfalfa hay offered in the paddock; FGM: same pasture and allowance as the control supplemented with a formulated grain mix containing wheat grain, corn grain, and canola meal fed in the parlor and alfalfa hay fed in the paddock; PMRL: same pasture and allowance as the control, supplemented with a PMR consisting of the same FGM but mixed with alfalfa hay and presented on a feed pad after each milking; and PMRH: same PMR fed in the same way as PMRL but with a higher pasture allowance. For all strategies, supplements provided the same metabolizable energy and grain:forage ratio [75:25, dry matter (DM) basis]. Each group of 24 cows was further allocated into 4 groups of 6 , which were randomly assigned to receive $8,12,14$, or $16 \mathrm{~kg}$ of DM supplement/cow per d. Thus, 2 replicated groups per supplement amount per dietary strategy were used. The experiment had a 14-d adaptation period and a 14-d measurement period. Pasture allowance, measured to ground level, was approximately $14 \mathrm{~kg}$ of $\mathrm{DM} / \mathrm{d}$ for control, FGM, and PMRL cows, and $28 \mathrm{~kg}$ of DM/d for the PMRH cows, and was offered in addition to the supplement. Positive linear responses to increasing amounts of supplement were observed for yield of milk, energy-corrected milk, fat, and protein for cows on all 4 supplement feeding strategies. Production of energycorrected milk was greatest for PMRH cows, intermediate for FGM and PMRL cows, and lowest for control cows. Some of these differences in milk production related to differences in intake of pasture and supple-
\end{abstract}

\footnotetext{
Received May 20, 2015.

Accepted September 17, 2015.

${ }^{1}$ Corresponding author: Martin.Auldist@ecodev.vic.gov.au
}

ment. Milk fat concentration decreased with increasing amount of supplement for all feeding strategies, but the decline was most marked for the control cows. Milk protein concentration increased for all groups as the amount of supplement increased, but was greater for FGM, PMRL, and PMRH cows than control cows. It is concluded that when supplements are fed to grazing dairy cows, inclusion of corn grain and canola meal can increase milk production even at similar metabolizable energy intakes, and that it does not matter whether these supplements are fed as a PMR or in the parlor and paddock.

Key words: partial mixed ration, pasture, milk response, supplements

\section{INTRODUCTION}

Grazed pasture is a major source of nutrients for dairy cattle in many parts of the world because of its inherent low cost (Doyle and Stockdale, 2011). In southeast Australia, pasture is commonly supplemented with cereal grain or pelleted concentrates, fed in the milking parlor, along with conserved forage fed in the paddock (Doyle et al., 2000). Below average rainfall, reduced availability of irrigation water and reduced pasture DM production in recent years have led to increased reliance on these supplements to meet the nutritional requirements of the milking herd (Wales et al., 2013).

Milk production often increases when cereal grain is fed in the parlor (Walker et al., 2001; Leddin et al., 2009), but the immediate marginal milk response decreases as the amount of grain increases (Stockdale et al., 1987; Walker et al., 2001; Kellaway and Harrington, 2004). Reductions in marginal milk production responses have been reported after as little as $5 \mathrm{~kg}$ of DM of grain is consumed (Stockdale et al., 1987; Walker et al., 2001). Such diminishing returns are due in part to inefficiencies in rumen fermentation when high levels of grain are ingested quickly (Dixon and Stockdale, 1999; Wales et al., 2000). Feeding high amounts of grain in the parlor can increase the variation in ruminal fluid $\mathrm{pH}$ and the time each day that it is below 6.0 (Wales and Doyle, 2003), which can impair NDF digestion (Mould et al., 
1983; Leddin et al., 2010), reduce DMI (Auldist et al., 2013), and reduce milk production (Doyle et al., 2005).

An alternative method of feeding supplements to grazing cows is to feed them as a partial mixed ration (PMR), defined as a TMR fed on a feed pad in between periods of grazing (Bargo et al., 2002). Dairy cows grazing a restricted pasture allowance supplemented with corn and canola-based PMR have shown greater milk production responses than cows offered similar amounts of supplementary energy as cereal grain in the parlor and conserved forage in the paddock (Auldist et al., 2013, 2014). It is possible that some of the increased milk production responses were due to the corn grain component providing a more slowly digestible source of starch than wheat grain (Khorasani et al., 2001), leading to less variable ruminal fluid $\mathrm{pH}$, and more stable and efficient rumen fermentation. Further, despite low pasture allowances, cows consuming PMR also grazed further into the pasture sward, substituted less pasture for supplement, and refused less supplement than cows at the highest rates of the other treatments. Thus, some of the production advantage of the PMR could also be due to increased DMI of both pasture and supplement.

One aim of the current experiment was to test whether the milk production advantage observed for cows fed PMR could be similarly realized by feeding the grain components in the parlor as a formulated grain mix. If so, the results would be relevant to a larger proportion of Australian dairy farmers, the vast majority of whom do not own mixer wagons or feed pads (Dairy Australia, 2015). A second aim was to determine the milk production of cows fed PMR and offered a generous pasture allowance, as opposed to the restricted allowance of previous experiments (Auldist et al., 2013, 2014). The hypotheses tested were that (1) feeding increasing amounts of a control diet of wheat grain in the parlor and lucerne hay in the paddock to cows grazing a restricted pasture allowance will increase ECM production; (2) feeding increasing amounts of a diet that is isoenergetic with the control diet, but which contains wheat grain, corn grain, canola meal, and alfalfa hay, and is fed to cows as a PMR on a feed pad after milking, will also increase ECM production in cows grazing restricted pasture, and that ECM production will be greater than for the control diet; (3) feeding increasing amounts of the same wheat grain, corn grain, and canola meal as in the PMR diet, but feeding it as a grain mix in the parlor with alfalfa hay fed in the paddock, will also lead to an increase in ECM production, and that ECM production will not be different from the PMR diet fed with the same restricted pasture allowance; and (4) when cows graze a high pasture allowance $(\sim 25 \mathrm{~kg}$ of $\mathrm{DM} /$ cow per d, measured to ground level) supplemented with PMR, ECM production will be greater than for cows grazing a restricted pasture allowance supplemented with the same PMR.

\section{MATERIALS AND METHODS}

The experiment was conducted in the spring at the Department of Economic Development, Jobs, Transport and Resources (DEDJTR), Ellinbank, Victoria, Australia $\left(38^{\circ} 14^{\prime} \mathrm{S}, 145^{\circ} 56^{\prime} \mathrm{E}\right)$. All procedures were conducted in accordance with the Australian Code of Practice for the Care and Use of Animals for Scientific Purposes (National Health and Medical Research Council, 2004). Approval to proceed was obtained from the DEDJTR Agricultural Research and Extension Animal Ethics Committee.

The experiment used 192 multiparous seasonally calving Holstein-Friesian dairy cows, including 16 rumenfistulated cows. All cows were in their second to fifth lactation and were milked twice daily at approximately 0700 and $1500 \mathrm{~h}$. Cows had calved in late winter/early spring and were, on average, 45 DIM (Table 1). All cows were weighed and their BCS assessed according to the 8-point scale of Earle (1976) immediately before the experiment.

The experiment was conducted over $28 \mathrm{~d}$. This included a 14-d pre-experimental period during which

Table 1. DIM, BW, BCS, and yields of milk, fat, and protein in the previous lactation for cows in the control, formulated grain mix (FGM), partial mixed ration, low pasture allowance (PMRL), and partial mixed ration, high pasture allowance (PMRH) groups at the start of the experiment $^{1}$

\begin{tabular}{lccrr}
\hline Item & Control & FGM & PMRL & PMRH \\
\hline DIM & $45( \pm 16.6)$ & $46( \pm 18.3)$ & $43( \pm 17.7)$ & $46( \pm 18.3)$ \\
BW (kg) & $595( \pm 51.1)$ & $597( \pm 61.1)$ & $591( \pm 52.9)$ & $4.5( \pm 0.22)$ \\
BCS $^{2}$ & $4.6( \pm 0.27)$ & $4.5( \pm 0.27)$ & $7.270( \pm 1,160)$ & $4.6( \pm 0.28)$ \\
Milk yield $^{3}$ & $7,370( \pm 1,394)$ & $7,140( \pm 1,282)$ & $300( \pm 48.7)$ & $7,280( \pm 1,282)$ \\
Fat yield $(\mathrm{kg})$ & $303( \pm 55.5)$ & $303( \pm 61.2)$ & $239( \pm 33.2)$ & $2402( \pm 58.1)$ \\
Protein yield $(\mathrm{kg})$ & $240( \pm 40.7)$ & $235( \pm 40.0)$ & & \\
\hline
\end{tabular}

${ }^{1}$ Data are means $( \pm \mathrm{SD})$ for the 48 cows in each group.

${ }^{2}$ BCS was assessed using the 8-point scale of Earle (1976).

${ }^{3}$ Yields of milk, fat, and protein are expressed as total yields in kilogram per cow for the preceding lactation. 
cows adapted to the amount and type of supplement. After the pre-experimental period, DMI and milk production were measured during a 14-d measurement period.

\section{Supplement Feeding Strategies}

As soon as all cows had calved they were allocated into 32 groups of 6 cows, balanced for DIM, age, BW, and production of milk, milk protein, and milk fat in the previous lactation according to the method of Baird (1994; Table 1). Groups were collected into 8 herds of 4 groups. Each one of the following 4 feeding strategies was then randomly assigned to 2 of the 8 herds (Table $2)$ :

(i) Control: cows grazed perennial ryegrass pasture (approximately $14.5 \mathrm{~kg}$ of $\mathrm{DM} /$ cow per d measured to ground level) supplemented with milled wheat grain, fed twice daily in the parlor during milking, and alfalfa hay, provided in the paddock. The ratio of grain to hay was 78:22 (DM basis).

(ii) Formulated grain mix (FGM): cows grazed perennial ryegrass pasture at the same allowance as the control cows. They also received a FGM, comprising milled wheat grain, crushed corn grain, and canola meal. This was fed twice daily in the parlor during milking. Cows also received alfalfa hay, provided in the paddock. The composition of the total diet (DM basis) was milled wheat grain $(38 \%)$, crushed corn grain $(18 \%)$, canola meal $(22 \%)$, and alfalfa hay $(22 \%)$. The ration in this treatment provided the same estimated ME intake as the supplements offered to the control cows, and had the same ratio of grain:forage (78:22 DM basis).

(iii) PMR, low pasture allowance (PMRL): cows grazed perennial ryegrass pasture at the same allowance as the control and FGM cows. They were also offered a PMR comprising milled wheat grain, crushed corn grain, canola meal, and alfalfa hay. This ration was assembled by mixing the FGM with alfalfa hay in a feed wagon (model K160; Richard Keenan and Co. Ltd., Co. Carlow, Ireland). These cows were also fed a small amount of their grain mix in the parlor at each milking (between 1.3 and $2.6 \mathrm{~kg}$ of DM/cow per $\mathrm{d}$ depending on the total supplement intake targeted). Water was mixed with the PMR such that the final DM concentration approximated $50 \%$, before it was presented on a concrete feed pad after each milking (half of the daily ration was fed after each milking). Consequently, the

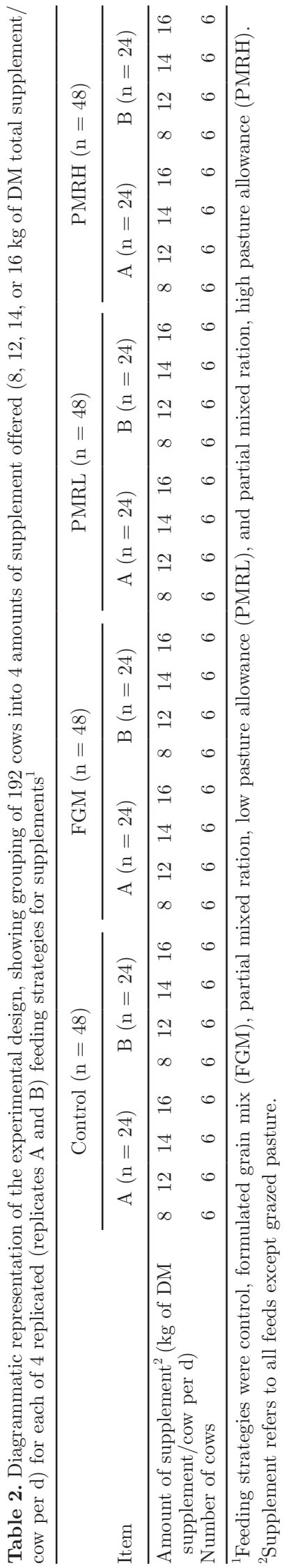

Journal of Dairy Science Vol. 99 No. 1, 2016 
PMR diet had the same components as the FGM, and the same estimated ME concentration and grain:forage ratio.

(iv) PMR, high pasture allowance (PMRH): Cows were subjected to the same dietary treatment as the PMRL cows, except that they were offered a higher pasture allowance (approximately $29 \mathrm{~kg}$ of $\mathrm{DM} /$ cow per d measured to ground level).

Nutritive characteristics of the ration components are presented in Table 3. As part of their supplement, all cows received a vitamin and mineral pellet (Nutrifeed Hi-Milker, Debenham Australia Pty Ltd., Leongatha, Victoria, Australia) that contained tylosin $(110 \mathrm{mg} / 100$ $\mathrm{g}$ of pellets) and monensin (110 mg/100 $\mathrm{g}$ of pellets). Cows at the highest rate of supplementation $(16 \mathrm{~kg}$ of $\mathrm{DM} /$ cow per $\mathrm{d}$ ) received these pellets at the rate recommended by the manufacturers (125 g pellet/ cow per d), whereas cows receiving lower amounts of supplement received proportionally less (e.g., cows offered $8 \mathrm{~kg}$ of DM supplement/d received $62.5 \mathrm{~g} /$ cow per $\mathrm{d}$ of the vitamin and mineral pellet). Control and FGM cows received their vitamin and mineral pellets mixed with their grain at milking time, whereas cows on the PMRL and PMRH diets received their pellets mixed into the PMR.

\section{Amounts of Supplement}

Within each herd, one group of 6 cows was randomly assigned to receive 1 of 4 amounts of supplement (supplement is defined in this experiment as all feed except grazed pasture and including both grain and forage). These were $8,12,14$, or $16 \mathrm{~kg}$ of $\mathrm{DM}$ total supplement/cow per d. Thus, 2 replicate groups of 6 cows per amount of supplement per feeding strategy were used (Table 2). Each group offered either 8 or $16 \mathrm{~kg}$ of DM total supplement/cow per d contained a rumen-fistulated cow, by placing a restriction on the randomization.
Cows fed PMR received their supplements on the feedpad, with groups of 6 cows separated by electric tapes. Control cows and FGM cows were fed their grain supplements in the milking parlor at each milking, whereas alfalfa hay was fed by placing the allocation for each group of 6 cows under an electric wire in their grazing area each day. Cows receiving the highest amounts of supplement (14 and $16 \mathrm{~kg}$ of DM/cow per d) were introduced gradually to dietary regimens, reaching their full amount of ration $5 \mathrm{~d}$ after the commencement of the pre-experimental period.

All cows had at least 6 opportunities each day to access water from troughs located in and adjacent to the milking parlor, and in laneways adjacent to the paddocks used for grazing.

\section{Supplement Intake and Nutritive Characteristics}

Samples of the ration components (FGM, wheat grain, and alfalfa hay) were collected on $3 \mathrm{~d} /$ wk during the measurement period and composited by week. Each sample was frozen, freeze-dried, ground through a 0.5 -mm sieve, and analyzed at a commercial laboratory (Dairy One Forage Laboratory, Ithaca, NY) for nutritive characteristics by near-infrared spectroscopy (AOAC International, 2000). Concentrations of estimated ME were calculated using the following formula (NRC, 2001):

$$
\begin{gathered}
\mathrm{ME}(\mathrm{MJ} / \mathrm{kg} \text { of } \mathrm{DM})= \\
\{[(1.01 \times(0.04409 \times \mathrm{TDN})]-0.45\} \times 4.184,
\end{gathered}
$$

where TDN is total digestible nutrient (\%).

Grain mix (control and FGM cows) and ration (PMR cows) offered and refused was weighed every day of the measurement period. Samples were collected and analyzed for DM and nutritive characteristics, which allowed the calculation of daily intake of DM, estimated $\mathrm{ME}, \mathrm{NDF}$, and CP for each group of cows. No refusals

\begin{tabular}{|c|c|c|c|c|c|c|c|c|c|}
\hline Item & $\mathrm{CP}$ & $\mathrm{ADF}$ & $\mathrm{NDF}$ & Lignin & $\mathrm{NFC}$ & Starch & $\mathrm{CF}^{2}$ & Ash & $\mathrm{ME}^{3}$ \\
\hline FGM & 19.8 & 10.2 & 19.2 & 3.6 & 57.0 & 43.7 & 3.3 & 4.0 & 13.3 \\
\hline Alfalfa hay & 19.4 & 36.8 & 45.1 & 9.1 & 31.2 & 1.2 & 1.9 & 7.9 & 9.3 \\
\hline $\mathrm{PMR}^{4}$ & 19.7 & 16.9 & 25.7 & 5.0 & 50.6 & 33.1 & 3.0 & 5.0 & 12.3 \\
\hline Crushed wheat & 13.0 & 4.7 & 12.1 & 0.8 & 73.1 & 54.4 & 2.3 & 2.1 & 14.6 \\
\hline Pasture offered & 17.0 & 33.2 & 53.7 & 4.3 & 20.4 & 0.8 & 3.6 & 9.2 & 9.9 \\
\hline Pasture residual & 13.1 & 38.4 & 64.2 & 4.5 & 13.3 & 1.0 & 2.4 & 9.9 & 8.7 \\
\hline Pasture consumed & 20.0 & 29.2 & 45.0 & 4.2 & 25.7 & 0.5 & 4.6 & 8.8 & 10.7 \\
\hline
\end{tabular}

Table 3. Mean nutritive characteristics of the formulated grain mix (FGM), alfalfa hay, partial mixed ration (PMR), crushed wheat and pasture

${ }^{1}$ Data are means (\% of DM unless otherwise indicated) for all samples collected during the 14-d measurement period.

${ }^{2}$ Crude fat.

${ }^{3}$ Estimated ME (MJ/kg of DM).

${ }^{4}$ Calculated from FGM and alfalfa hay data. 
of alfalfa hay in the paddocks (control and FGM cows) were observed; therefore, it was assumed that all hay was consumed.

\section{Grazing}

Cows grazed in groups of 6 on adjacent areas separated from the other groups by electric fences. The 8 herds were grazed separately in paddocks that were divided into 4 strips for the 4 feeding rate groups within each herd. The treatment sequence of paddocks was randomized, as was the allocation of feed-rates to strips within paddocks. Cows were prevented from re-grazing areas grazed on previous days through the use of backfencing.

For control, FGM, and PMRL cows, pasture allowance was approximately $14.5 \mathrm{~kg}$ of $\mathrm{DM} / \mathrm{cow}$ per day (to ground level) and was available as a single plot of approximately 0.02 ha of pasture per day. For PMRH cows, pasture allowance was approximately $29 \mathrm{~kg}$ of $\mathrm{DM} /$ cow per day. This was achieved by giving these cows twice the area of the cows on the other feeding strategies. All cows received their pasture in 2 fresh allocations per day, provided postmilking. Control and FGM cows had access to pasture immediately after each milking, whereas cows fed according to the PMRL and PMRH strategies had access to pasture after they had consumed their PMR on the feed pad following each milking.

\section{Pasture Intake and Nutritive Characteristics}

Pre- and postgrazing pasture mass was estimated using a rising plate meter (Ellinbank Plate Meter; Earle and McGowan, 1979). Each day of the measurement period, for each group of 6 cows, 100 readings were taken pre- and postgrazing in a zig-zag pattern down the allocated plot of pasture. The pasture meter was calibrated for each new set of paddocks the cows entered by using quadrant cuts to construct calibration equations plotting actual pasture mass against pasture meter reading. This information was used to calculate average pasture DMI for each group.

Samples of pasture were collected pre- and postgrazing from each of the 32 groups of 6 cows due to potential differences in nutritive characteristics and residual pasture mass. All samples were collected by cutting pasture to ground level using electric shears at several points along a transect of the grazing area.

Pasture samples were thoroughly mixed, then subsampled, washed (postgrazing samples only), freezedried, and ground through a $0.5-\mathrm{mm}$ sieve. Dried samples were analyzed for nutritive characteristics as described for the supplements. Data from pre- and postgrazing pasture samples were combined with estimates of pre- and postgrazing mass to calculate the nutritive characteristics of pasture consumed.

\section{Ruminal Fluid VFA, Ammonia, and $\mathrm{pH}$}

Samples of rumen fluid were collected from each of the rumen-fistulated cows at intervals of approximately $2 \mathrm{~h}$ over a 24 -h period during the measurement period. This was done by restraining the cows in temporary yards set up in the paddock, or in permanent yards next to the feedpad and milking parlor. Samples were collected per fistulae using a $100-\mathrm{mL}$ plastic syringe connected to a copper pipe inserted into the ruminal contents. Samples were immediately analyzed for $\mathrm{pH}$ using a portable $\mathrm{pH}$ meter (Mettler-Toledo FG2 pH meter, Schwerzenbach, Switzerland).

For VFA analyses, a 5-mL aliquot of rumen fluid was dispensed into a tube containing 2 drops of concentrated $\mathrm{H}_{2} \mathrm{SO}_{4}$ and stored at $-20^{\circ} \mathrm{C}$ until analysis. Concentrations of VFA were determined by capillary gas chromatography using the method of Supelco, Bulletin no. 749D (Supelco Inc., Bellefonte, PA). Results were calculated as parts per million and converted to millimoles per liter. The ratio of acetate plus butyrate to propionate $[(\mathrm{A}+\mathrm{B}) / \mathrm{P}]$ was calculated from molar concentrations.

For ammonia-N analysis, an aliquot of $10 \mathrm{~mL}$ of ruminal fluid was dispensed into a tube and stored at $-20^{\circ} \mathrm{C}$ until analysis. Concentrations of ammonia were assayed by a direct enzymatic procedure using a commercially available kit (Beckman Coulter Australia Pty Ltd., Melbourne, Victoria, Australia) and an Olympus AU400 autoanalyzer (Olympus Australia Pty Ltd., Melbourne Victoria, Australia).

\section{Milk Yield and Composition}

Milk yield of every cow was measured at every milking during both the pre-experimental and measurement periods using a DeLaval Alpro milk metering system (DeLaval International, Tumba, Sweden). Fat and protein concentrations of the daily milk from each cow were determined on $3 \mathrm{~d} /$ wk during the measurement period. This was done by using in-line milk meters (DeLaval International) to collect representative milk samples from consecutive afternoon and morning milkings, analyzing the p.m. and a.m. milk separately, then calculating a weighted average in proportion to the yield at each milking. Milk samples were tested for concentrations of protein and fat using an infrared milk analyzer (model 2000, Bentley Instruments, Chaska, 
MN). Energy-corrected milk, standardized to $4.0 \%$ fat and $3.3 \%$ protein, was calculated using the following formula (Tyrrell and Reid, 1965):

$$
\begin{gathered}
\text { ECM }(\mathrm{kg} / \text { cow per d })=\text { milk yield } \mathrm{kg} \\
\times(376 \times \text { fat } \%+209 \times \text { protein } \%+948) / 3,138
\end{gathered}
$$

\section{Statistical Analyses}

All data were averaged over time for each cow within the experimental period, and where relevant, averaged over cows within groups before statistical analysis. Pasture and supplement intake data, and rumen data, were analyzed by ANOVA with factorial treatment structure, feeding strategy by amount, with blocking structure, herd split for group. Milk and milk composition data were analyzed by a general mixed model with fixed effects of the variable measured in the covariate period, feeding strategy, linear and quadratic terms for observed DMI, and their interactions with feeding strategy. Random effects were included for herd and group within herd. For presentation, quadratic and interaction terms were dropped where nonsignificant, and predicted means calculated at hypothetical DMI of $9,10,11,12,13,14,15$, and $16 \mathrm{~kg} / \mathrm{cow}$ per $\mathrm{d}$ for each feeding strategy. Linear relationships between milk production variables and supplement DMI were estimated within the mixed model with fixed effects for covariate-period milk production and feeding strategy by supplement DMI (uncentered).

All data analyses were conducted using ANOVA or REML in GenStat 16 software for Windows (Genstat release 16; VSN International Ltd., Hemel Hempstead, UK). Distributional assumptions of normality and constant variance were checked graphically using plots of residuals versus fitted values, histograms of residuals, and normal quantile plots.

\section{RESULTS}

\section{Nutritive Characteristics of Feed}

Concentrations of $\mathrm{CP}, \mathrm{ADF}, \mathrm{NDF}$, lignin, NFC, starch, crude fat, ash, and estimated ME in the FGM, alfalfa hay, PMR, wheat grain, and pasture (offered, residual, and consumed) are presented in Table 3.

\section{Pasture Allowances, Utilization, and Intakes}

Pre-grazing pasture mass did not differ between feeding strategies $(P=0.132)$ or amounts of supplement offered $(P=0.765)$. Pasture allowance was different between feeding strategies $(P<0.001)$ because, by design, pasture allowance was approximately twice as great for the PMRH cows as for cows fed according to the other 3 feeding strategies. Pasture allowance did not differ between groups offered the same amounts of supplement $(P=0.178)$.

Postgrazing pasture mass increased as amount of supplement offered increased $(P=0.001)$, and was higher for pasture grazed by PMRH cows than by cows in the other feeding strategies $(P<0.001)$. As a consequence, pasture DMI $(P<0.001)$ and intake of estimated ME from pasture $(P=0.034)$ decreased as the amount of supplement offered increased, as did pasture utilization (defined as the percentage of pasture on offer, measured to ground level, which was consumed; $P<0.001)$. Pasture DMI $(P<0.001)$ and estimated ME intake from pasture $(P=0.003)$ were affected by feeding strategy, and were higher for PMRH cows than cows on the other feeding strategies, and higher for FGM than control cows. Pasture utilization was also affected by feeding strategy $(P<0.001)$, being lower in the PMRH treatment than the other treatments, and higher for the FGM treatment than the control treatment.

\section{Supplement Intakes and Total Intakes}

By design, supplement DMI and estimated ME intake from supplement both increased $(P<0.001)$ as the amount of supplement offered increased (Table 4 ). Supplement DMI was lower $(P=0.003)$, but intake of ME from supplement was higher $(P<0.001)$ for control cows than cows fed according to the other 3 strategies. Total DMI and estimated ME intakes increased $(P<$ 0.001 ) with increasing amounts of supplement offered, and were also affected by feeding strategy $(P=0.005)$. Cows fed according to the PMRH strategy had higher DMI and ME intakes than cows fed according to the other 3 strategies. Cows fed according to the FGM and PMRL strategies had higher total DMI than the control cows, but similar total intakes of estimated ME.

\section{Milk Yield and Composition}

Mean yields of milk, ECM, fat, and protein, and mean concentrations of milk fat and protein, for cows fed according to the 4 dietary strategies at the different supplement levels are presented in Figure 1, along with fitted relationships for each parameter measured. The equations describing these relationships are presented in Table 6. With the exception of the milk fat concentration response function for cows fed according to the PMRH strategy, none of the 4 diet strategies 


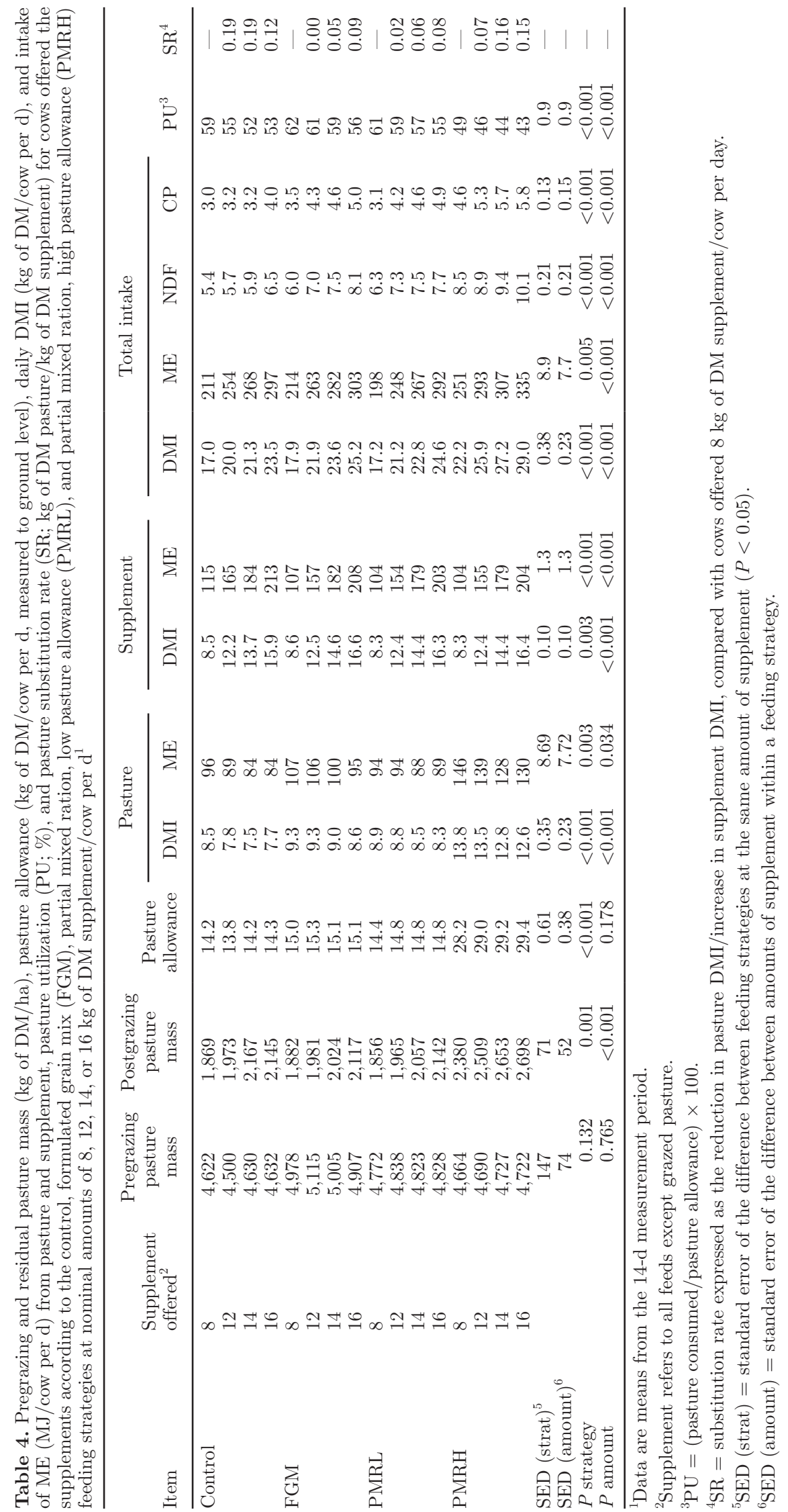



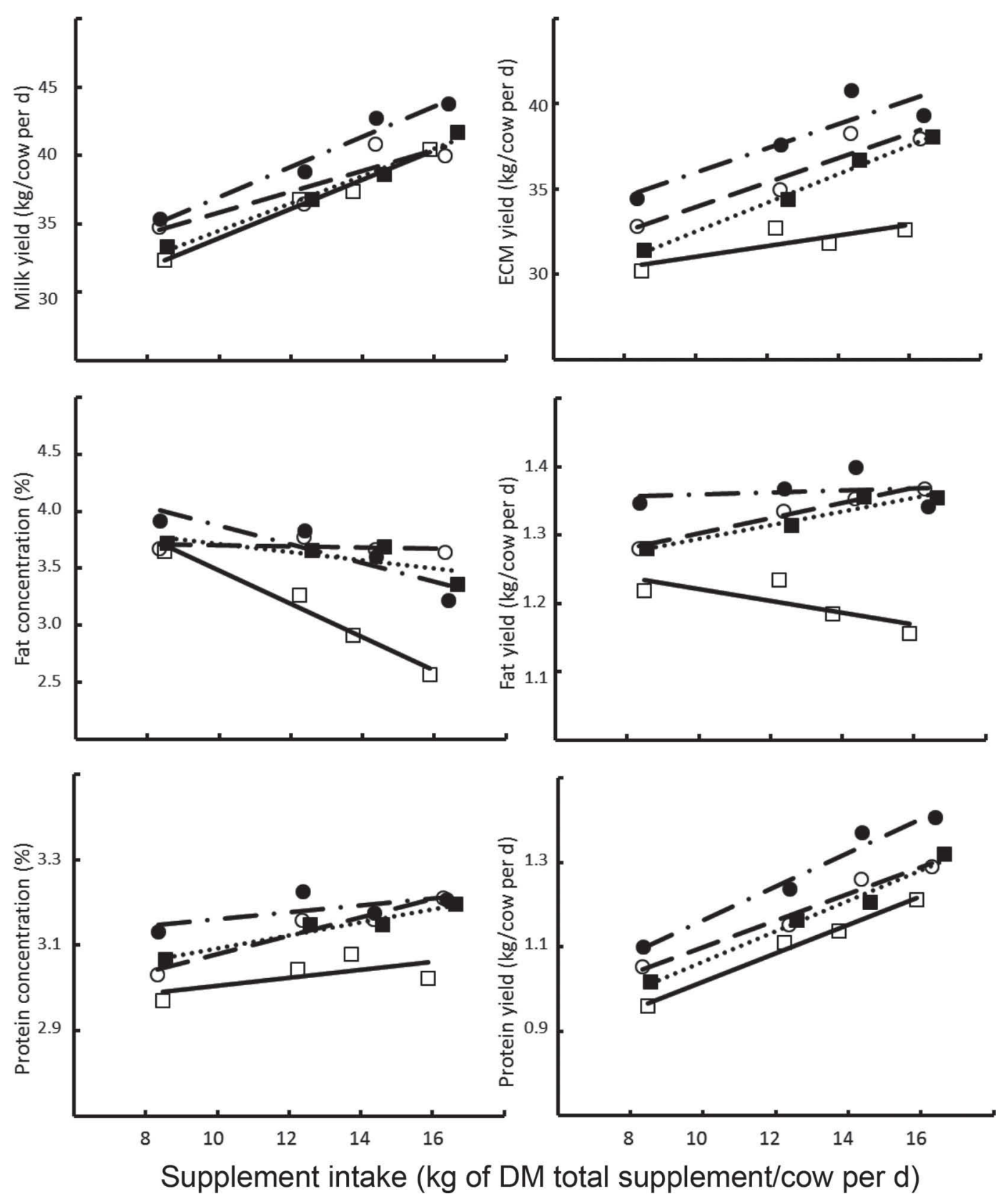

Figure 1. Mean daily yields of milk and ECM, and concentrations and yields of milk protein and fat, for cows offered supplements according to the control $(\square)$, formulated grain mix (FGM; $\square$ ), partial mixed ration, low pasture allowance (PMRL; $\bigcirc)$, or partial mixed ration, high pasture allowance $(\mathrm{PMRH} ; \bullet)$ feeding strategies at nominal amounts of approximately 8, 12, 14, or $16 \mathrm{~kg}$ of DM supplement/cow per d. Data are means from the 14-d measurement period. Relationships were fitted for the control (solid line), FGM (dotted line), PMRL (long dashed line), and PMRH (dotted-dashed line) supplements.

had significant $(P<0.05)$ quadratic components of the response relationship for any parameter, so all relationships are presented as linear.

Fitted relationships were used to derive predicted means for yields of milk, ECM, fat, and protein, and concentrations of fat and protein in milk, for cows fed according to the 4 dietary strategies at supplement intakes of $9,10,11,12,13,14,15$, and $16 \mathrm{~kg}$ of $\mathrm{DM}$ supplement/cow per d (Table 5).

Milk yield increased $(P<0.001$; Table 6$)$ with increasing supplement intake for all feeding strategy groups (Figure 1). No difference was found in milk yield $(P>$ 
Table 5. Mean daily yields of milk (MY) and ECM, and concentrations and yields of milk protein (P\% and PY) and fat (F\% and FY), for cows offered different amounts of supplement according to the control, formulated grain mix (FGM), partial mixed ration, low pasture allowance (PMRL) and partial mixed ration, high pasture allowance $(\mathrm{PMRH})$ feeding strategies ${ }^{1}$

\begin{tabular}{|c|c|c|c|c|c|c|c|c|c|}
\hline Parameter & $\begin{array}{l}\text { Feeding } \\
\text { strategy }\end{array}$ & \multicolumn{8}{|c|}{ Total supplement offered ${ }^{2}$ ( $\mathrm{kg}$ of $\mathrm{DM} /$ cow per d) } \\
\hline \multirow[t]{4}{*}{ MY } & Control & $32.9^{\mathrm{a}}$ & $34.0^{\mathrm{a}}$ & $35.0^{\mathrm{a}}$ & $36.1^{\mathrm{a}}$ & $37.2^{\mathrm{a}}$ & $38.2^{\mathrm{a}}$ & $39.3^{\mathrm{a}}$ & $40.4^{\mathrm{a}}$ \\
\hline & PMRL & $35.1^{\mathrm{ab}}$ & $35.8 \mathrm{a}^{\mathrm{b}}$ & $36.6^{\mathrm{ab}}$ & $37.4^{\mathrm{ab}}$ & $38.1^{\mathrm{a}}$ & $38.9^{\mathrm{a}}$ & $39.7^{\mathrm{a}}$ & $40.4^{\mathrm{a}}$ \\
\hline & PMRH & $35.9^{\mathrm{b}}$ & $37.0^{\mathrm{b}}$ & $38.1^{\mathrm{b}}$ & $39.2^{\mathrm{b}}$ & $40.3^{\mathrm{b}}$ & $41.1^{\mathrm{b}}$ & $42.5^{\mathrm{b}}$ & $43.6^{\mathrm{b}}$ \\
\hline & $\mathrm{SED}^{3}$ & 1.24 & 1.05 & 0.90 & 0.79 & 0.76 & 0.80 & 0.91 & 1.07 \\
\hline \multirow{3}{*}{$\mathrm{ECM}$} & PMRL & $33.2^{\mathrm{b}}$ & $33.9^{\mathrm{b}}$ & $34.6^{\mathrm{b}}$ & $35.3^{\mathrm{b}}$ & $36.1^{\mathrm{b}}$ & $36.8^{\mathrm{b}}$ & $37.5^{\mathrm{b}}$ & $38.2^{\mathrm{b}}$ \\
\hline & PMRH & $35.4^{\mathrm{c}}$ & $36.1^{\mathrm{c}}$ & $36.8^{\mathrm{c}}$ & $37.5^{\mathrm{c}}$ & $38.2^{\mathrm{c}}$ & $38.8^{\mathrm{c}}$ & $39.5^{\mathrm{c}}$ & $40.2^{\mathrm{c}}$ \\
\hline & SED & 1.06 & 0.89 & 0.76 & 0.68 & 0.67 & 0.72 & 0.83 & 0.97 \\
\hline \multirow[t]{4}{*}{$\mathrm{F} \%$} & Control & $3.64^{\mathrm{a}}$ & $3.49^{\mathrm{a}}$ & $3.34^{\mathrm{a}}$ & $3.19^{\mathrm{a}}$ & $3.04^{\mathrm{a}}$ & $2.88^{\mathrm{a}}$ & $2.73^{\mathrm{a}}$ & $2.58^{\mathrm{a}}$ \\
\hline & FGM & $3.74^{\mathrm{ab}}$ & $3.71^{\mathrm{b}}$ & $3.67^{\mathrm{b}}$ & $3.64^{\mathrm{b}}$ & $3.61^{\mathrm{b}}$ & $3.58^{\mathrm{b}}$ & $3.55^{\mathrm{ab}}$ & $3.51^{\mathrm{b}}$ \\
\hline & PMRL & $3.70^{\mathrm{a}}$ & $3.70^{\mathrm{b}}$ & $3.69^{\mathrm{b}}$ & $3.69^{\mathrm{b}}$ & $3.68^{\mathrm{b}}$ & $3.67^{\mathrm{b}}$ & $3.67^{\mathrm{b}}$ & $3.66^{\mathrm{c}}$ \\
\hline & PMRH & $3.98^{\mathrm{b}}$ & $3.89^{\mathrm{b}}$ & $3.81^{\mathrm{b}}$ & $3.72^{\mathrm{b}}$ & $3.64^{\mathrm{b}}$ & $3.55^{\mathrm{b}}$ & $3.47^{\mathrm{c}}$ & $3.38^{\mathrm{b}}$ \\
\hline FY & SED & 0.026 & 0.022 & 0.019 & 0.016 & 0.015 & 0.017 & 0.020 & 0.023 \\
\hline \multirow[t]{5}{*}{$\mathrm{P} \%$} & Control & $2.99^{\mathrm{a}}$ & $3.00^{\mathrm{a}}$ & $3.01^{\mathrm{a}}$ & $3.02^{\mathrm{a}}$ & $3.03^{\mathrm{a}}$ & $3.04^{\mathrm{a}}$ & $3.05^{\mathrm{a}}$ & $3.06^{\mathrm{a}}$ \\
\hline & FGM & $3.08^{\mathrm{bc}}$ & $3.10^{\mathrm{b}}$ & $3.11^{\mathrm{b}}$ & $3.12^{\mathrm{b}}$ & $3.14^{\mathrm{b}}$ & $3.15^{\mathrm{b}}$ & $3.17^{\mathrm{b}}$ & $3.18^{\mathrm{b}}$ \\
\hline & PMRL & $3.06^{\mathrm{ab}}$ & $3.08^{\mathrm{b}}$ & $3.10^{\mathrm{b}}$ & $3.12^{\mathrm{b}}$ & $3.15^{\mathrm{bc}}$ & $3.17^{\mathrm{b}}$ & $3.19^{\mathrm{b}}$ & $3.21^{\mathrm{b}}$ \\
\hline & PMRH & $3.15^{\mathrm{c}}$ & $3.16^{\mathrm{c}}$ & $3.17^{\mathrm{c}}$ & $3.18^{\mathrm{c}}$ & $3.19^{\mathrm{c}}$ & $3.20^{\mathrm{b}}$ & $3.20^{\mathrm{b}}$ & $3.21^{\mathrm{b}}$ \\
\hline & SED & 0.035 & 0.030 & 0.025 & 0.022 & 0.021 & 0.023 & 0.027 & 0.032 \\
\hline \multirow[t]{5}{*}{ PY } & Control & $0.98^{\mathrm{a}}$ & $1.02^{\mathrm{a}}$ & $1.05^{\mathrm{a}}$ & $1.09^{\mathrm{a}}$ & $1.12^{\mathrm{a}}$ & $1.15^{\mathrm{a}}$ & $1.19^{\mathrm{a}}$ & $1.22^{\mathrm{a}}$ \\
\hline & FGM & $1.03^{\mathrm{ab}}$ & $1.06^{\mathrm{ab}}$ & $1.10^{\mathrm{b}}$ & $1.14^{\mathrm{b}}$ & $1.17^{\mathrm{b}}$ & $1.21^{\mathrm{b}}$ & $1.25^{\mathrm{b}}$ & $1.28^{\mathrm{b}}$ \\
\hline & PMRL & $1.07^{\mathrm{bc}}$ & $1.10^{\mathrm{b}}$ & $1.13^{\mathrm{b}}$ & $1.16^{\mathrm{b}}$ & $1.19^{\mathrm{b}}$ & $1.23^{\mathrm{b}}$ & $1.26^{\mathrm{b}}$ & $1.29^{\mathrm{b}}$ \\
\hline & PMRH & $1.12^{\mathrm{c}}$ & $1.16^{\mathrm{c}}$ & $1.20^{\mathrm{c}}$ & $1.24^{\mathrm{c}}$ & $1.28^{\mathrm{c}}$ & $1.32^{\mathrm{c}}$ & $1.36^{\mathrm{c}}$ & $1.40^{\mathrm{c}}$ \\
\hline & SED & 0.028 & 0.024 & 0.020 & 0.018 & 0.017 & 0.018 & 0.021 & 0.025 \\
\hline
\end{tabular}

${ }^{\mathrm{a}-\mathrm{c}}$ Within amounts of supplement offered (columns) for each milk parameter measured, means with different superscripts are significantly different $(P>0.05)$.

${ }^{1}$ All yields are expressed as kilogram per cow per day. Data are predicted means from the 14-d measurement period.

${ }^{2}$ Supplement refers to all feeds except grazed pasture.

${ }^{3} \mathrm{SED}=$ standard error of the difference.

0.05 ) between control and FGM cows at any amount of supplement intake (Table 5). Milk yield for PMRH cows was higher than for control and FGM cows at almost all amounts of supplement intake, whereas milk yield for PMRL cows was intermediate to control and PMRH cows.

The ECM also increased $(P<0.001$; Table 6$)$ with increasing supplement intake for all feeding strategies except the control (Figure 1). Yield of ECM was always greater for PMRH cows than cows on the other strategies. No difference was found in the ECM yields of cows fed according to the FGM and PMRL strategies, but these cows yielded more ECM than control cows at almost all amounts of supplement offered (Table 5).

Fat concentration in the milk of control cows was lower than for milk from cows fed supplement according to the other 3 feeding strategies at almost all amounts of supplement offered (Table 5). In the control cows, milk fat concentration declined markedly with increas- ing amount of supplement offered, but in the other 3 groups this decline was much less pronounced or absent (Figure 1; Table 6).

Fat yield was also lower $(P<0.05)$ for control cows than for cows fed according to the other 3 feeding strategies, at each amount of supplement offered (Table 5). Little difference was found between the fat yield of FGM and PMRL cows, but PMRH cows yielded more milk fat than the 3 other groups at almost all amounts of supplement offered. For control cows, fat yield declined with increasing amount of supplement offered, but increased slightly or was stable for the other groups (Figure 1; Table 6).

Concentrations and yields of milk protein were lowest $(P<0.05)$ in milk from the control cows, highest $(P<0.05)$ in PMRH cows, and intermediate in the FGM and PMRL cows (Table 5). Yields of milk protein increased for all groups as the amount of supplement offered increased (Figure 1; Table 6). 
Table 6. Equations ${ }^{1}$ describing the relationships between supplement DMI (kg of DM total supplement/cow per $\mathrm{d}^{2}$ ) and milk yield (MY), ECM, fat concentration (F\%), fat yield (FY), protein concentration (P\%), and protein yield (PY), for cows offered supplements according to the control, formulated grain mix (FGM), partial mixed ration, low pasture allowance (PMRL), and partial mixed ration, high pasture allowance (PMRH) feeding strategies

\begin{tabular}{|c|c|c|c|}
\hline Parameter & $\begin{array}{l}\text { Feeding } \\
\text { strategy }\end{array}$ & Equation & $\begin{array}{l}P \text {-value of } \\
\text { linear trend }\end{array}$ \\
\hline \multirow[t]{4}{*}{$\mathrm{MY}(\mathrm{kg} /$ cow per d) } & Control & $\mathrm{MY}=23.29+1.07 \mathrm{DMI}$ & $<0.001$ \\
\hline & FGM & $\mathrm{MY}=24.49+1.00 \mathrm{DMI}$ & $<0.001$ \\
\hline & PMRL & $\mathrm{MY}=28.18+0.77 \mathrm{DMI}$ & $<0.001$ \\
\hline & PMRH & $\mathrm{MY}=26.04+1.10 \mathrm{DMI}$ & $<0.001$ \\
\hline \multirow[t]{4}{*}{ ECM (kg/cow per d) } & Control & $\mathrm{ECM}=27.96+0.30 \mathrm{DMI}$ & 0.065 \\
\hline & FGM & $\mathrm{ECM}=24.09+0.85 \mathrm{DMI}$ & $<0.001$ \\
\hline & PMRL & $\mathrm{ECM}=26.65+0.72 \mathrm{DMI}$ & $<0.001$ \\
\hline & PMRH & $\mathrm{ECM}=29.31+0.68 \mathrm{DMI}$ & $<0.001$ \\
\hline \multirow[t]{4}{*}{$\mathrm{F} \%$} & Control & $\mathrm{F} \%=4.990-0.150 \mathrm{DMI}$ & $<0.001$ \\
\hline & FGM & $\mathrm{F} \%=4.025-0.032 \mathrm{DMI}$ & 0.736 \\
\hline & PMRL & $\mathrm{F} \%=3.753-0.006 \mathrm{DMI}$ & $<0.001$ \\
\hline & PMRH & $\mathrm{F} \%=4.745-0.085 \mathrm{DMI}$ & 0.068 \\
\hline \multirow[t]{4}{*}{ FY $(\mathrm{kg} /$ cow per d) } & Control & $\mathrm{FY}=1.317-0.0096 \mathrm{DMI}$ & 0.022 \\
\hline & FGM & $\mathrm{FY}=1.1905+0.0105 \mathrm{DMI}$ & 0.007 \\
\hline & PMRL & $\mathrm{FY}=1.1865+0.0113 \mathrm{DMI}$ & 0.004 \\
\hline & PMRH & $\mathrm{FY}=1.3676-0.0002 \mathrm{DMI}$ & 0.963 \\
\hline \multirow[t]{4}{*}{$\mathrm{P} \%$} & Control & $\mathrm{P} \%=2.910+0.009 \mathrm{DMI}$ & 0.099 \\
\hline & FGM & $\mathrm{P} \%=2.946+0.015 \mathrm{DMI}$ & 0.006 \\
\hline & PMRL & $\mathrm{P} \%=2.857+0.022 \mathrm{DMI}$ & $<0.001$ \\
\hline & PMRH & $\mathrm{P} \%=3.076+0.009 \mathrm{DMI}$ & 0.098 \\
\hline \multirow[t]{4}{*}{ PY (kg/cow per d) } & Control & $\mathrm{PY}=0.6814+0.0337 \mathrm{DMI}$ & $<0.001$ \\
\hline & FGM & $\mathrm{PY}=0.7036+0.0361 \mathrm{DMI}$ & $<0.001$ \\
\hline & PMRL & $\mathrm{PY}=0.7853+0.0315 \mathrm{DMI}$ & $<0.001$ \\
\hline & PMRH & $\mathrm{PY}=0.7601+0.0402 \mathrm{DMI}$ & $<0.001$ \\
\hline
\end{tabular}

${ }^{1}$ These equations are derived from relationships fitted to the mean measured values at 4 amounts of supplement intake per feeding strategy. Quadratic contrasts were not significant and are not shown.

${ }^{2}$ Supplement refers to all feeds except grazed pasture.

\section{Marginal ECM Responses to Supplement}

Predicted marginal responses in ECM yield to increasing intakes of supplement ( $\mathrm{kg}$ of $\mathrm{ECM} / \mathrm{kg}$ of supplement DM) were $0.30,0.85,0.72$, and 0.68 for the control, FGM, PMRL, and PMRH groups, respectively. The marginal ECM production responses of the control cows were lower $(P>0.05)$ than that of the FGM, PMRL, and PMRH cows.

\section{Ruminal Fluid pH, VFA, and Ammonia}

No differences $(P>0.10)$ were found between feeding strategies for time under $\mathrm{pH} 6.0$, area under $\mathrm{pH} 6.0$, maximum $\mathrm{pH}$, minimum $\mathrm{pH}, \mathrm{pH}$ nadir after $7 \mathrm{~h}$, or mean daily $\mathrm{pH}$. An influence was found of the amount of supplement on $\mathrm{pH}$ nadir after $7 \mathrm{~h}$, which was lower in cows fed more supplement (Table 7). Also, a trend $(P<0.10)$ was found for cows fed more supplement to have a lower mean daily $\mathrm{pH}$, more time under $\mathrm{pH} 6.0$, and a greater area under $\mathrm{pH} 6.0$.

Concentrations of total VFA for cows, along with proportions of acetic $(\mathrm{A})$, propionic $(\mathrm{P})$, butyric $(\mathrm{B})$, and valeric acids, ammonia, and the $(\mathrm{A}+\mathrm{B}) / \mathrm{P}$ ratio, in ruminal fluid from cows on the 4 feeding strategies at lowest and highest amounts of supplement intake are presented in Table 8. Dietary strategy had no effect $(P$ $>0.10)$ on any of these variables. However, the proportions of acetic and butyric acid decreased as amount of supplement offered increased $(P<0.05)$, while the proportions of propionic and valeric acid increased $(P<$ $0.05)$. The $(\mathrm{A}+\mathrm{B}) / \mathrm{P}$ ratio decreased $(P<0.001)$ with increasing amounts of supplement offered, whereas a trend $(P<0.10)$ was observed for the amount of total VFA to increase.

\section{DISCUSSION}

Milk production responses to feeding supplementary cereal-based concentrates in the parlor at milking times to cows that derive a high proportion of their nutrients from grazed pasture have been studied for many years and are well-described (Doyle et al., 2001). Milk production usually increases when cereal grain is fed to grazing cows (Walker et al., 2001; Leddin et al., 2009), but the amount of milk produced from each additional kilogram of grain decreases as the amount of grain increases (Walker et al., 2001; Leddin et al., 2009). Such 

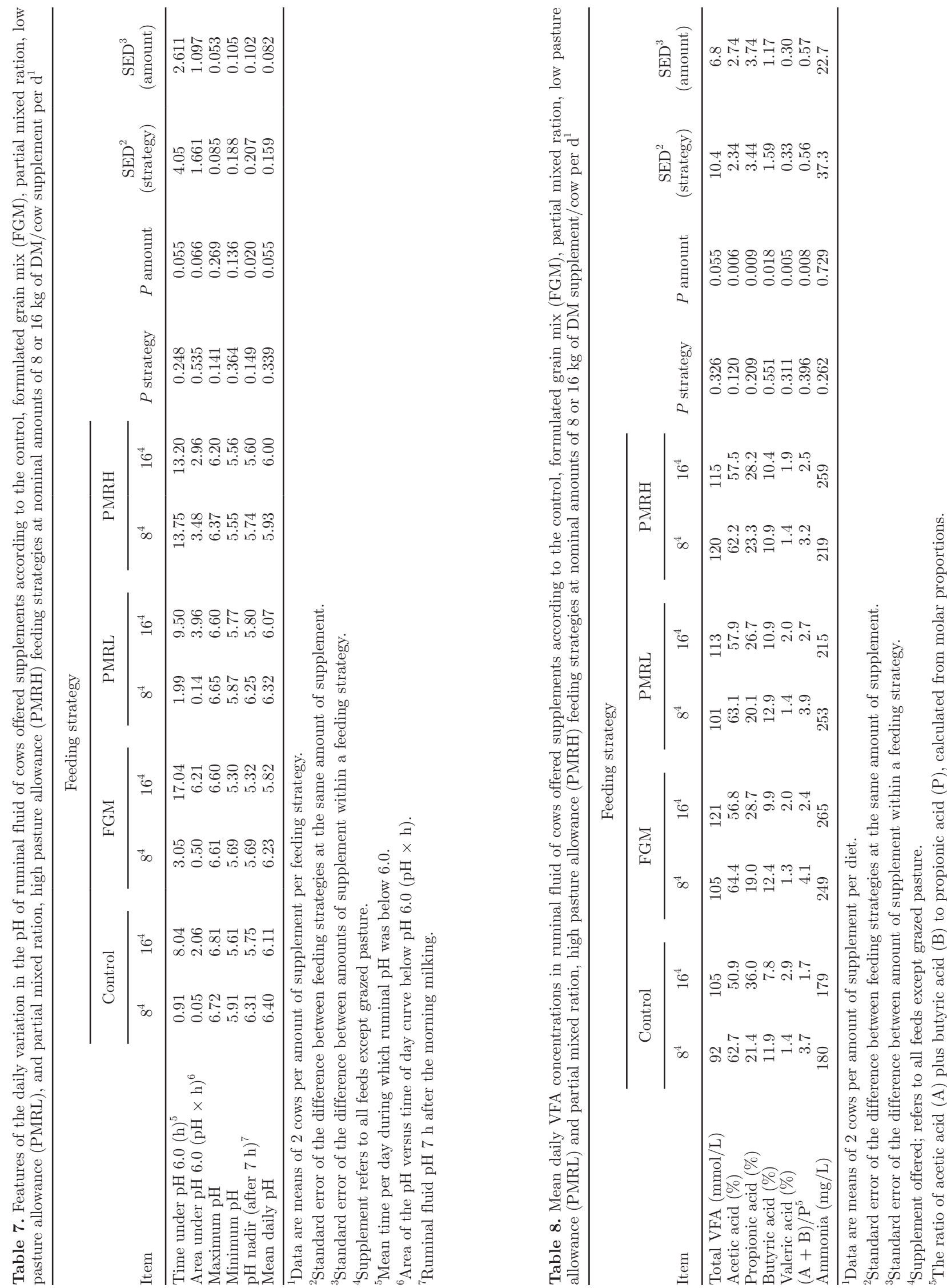
diminishing returns are due, in part, to inefficiencies in rumen fermentation and reduced NDF digestion when high amounts of grain are ingested quickly (Dixon and Stockdale, 1999; Wales et al., 2000). An increase in ECM production was observed in the control cows in the current experiment as the amount of supplement offered increased from 8 to $16 \mathrm{~kg}$ of DM/cow per $\mathrm{d}$, and thus the first hypothesis is accepted. It is important to note, however, that although the milk production response relationships are presented as linear relationships in the current manuscript, it is biologically unlikely that they are so for the reasons given above. They are presented this way for the purpose of comparison between feeding strategies because statistically significant quadratic relationships could not be shown over the range of supplement intakes shown.

Previous experiments have shown that immediate milk production responses in grazing cows can be increased when supplements are offered as PMR on a feed pad, compared with feeding the same amount of estimated ME as cereal grain in the parlor and forage in the paddock (Auldist et al., 2013, 2014). Limited previous experiments from countries other than Australia have similarly shown that increasing proportions of PMR in the diets of pasture-fed dairy cows can increase milk production (Bargo et al., 2002; Vibart et al., 2008). This was also observed in the current experiment, with PMRL cows producing more ECM than control cows at all amounts of supplement offered. Thus the second hypothesis is accepted.

Auldist et al. (2013, 2014) concluded that the increased milk production in cows fed a PMR compared with control cows fed the same amount of $\mathrm{ME}$ as grain in the parlor and forage in the paddock was not due to changes in the physical form of the diet, but to the PMR containing a more slowly digestible starch source (corn) and having an elevated concentration of $\mathrm{CP}$ (provided via canola meal). It was for this reason that we included in the current experiment a feeding strategy that had exactly the same dietary components as were fed in the PMR but offered as a grain mix fed in the parlor, with the forage component (alfalfa hay) fed in the paddock. The results showed no differences in the ECM yield of cows fed according to the PMRL and FGM strategies at any amount of supplement offered, and that the ECM yields of these cows were always greater than those of the control cows. Thus the third hypothesis is accepted. This finding has important practical implications because it indicates that the milk production benefits of PMR could be largely captured using existing feeding infrastructure in the parlor, thus mitigating the requirement for farmers to invest in feed pads and mixer wagons.
The mechanisms behind the increased milk response of cows fed supplements as a PMR or FGM compared with cows fed cereal grain in the parlor and forage in the paddock (control) are uncertain, but are likely to be multifold. Some of the increased ECM response in PMRL and FGM cows compared with control cows could be attributed to an increase in DMI. Although pasture allowances for cows offered supplements according to the control, FGM, and PMRL feeding strategies were low and similar, and were set to minimize differences in pasture intake between the different groups, PMRL and FGM cows still consumed greater amounts of pasture than control cows when the amount of supplement offered was $12 \mathrm{~kg}$ of $\mathrm{DM} /$ cow per d or greater. For example, PMRL cows offered $14 \mathrm{~kg}$ of DM supplement/d ate $0.9 \mathrm{~kg}$ of $\mathrm{DM} / \mathrm{d}$ more pasture than control cows offered the same amount of supplement.

Such an increase in pasture intake in cows fed PMR compared with control cows was reported previously by Auldist et al. (2013, 2014) for cows grazing a restricted pasture allowance. This was the reason for including in the current experiment a feeding strategy in which pasture allowance was not limiting. If cows fed PMR are more inclined to consume pasture than control cows even when grazing a restricted pasture allowance then it was of interest to see how much extra pasture they would consume (and therefore how much more milk they would produce) if allowed the opportunity through the provision of a generous pasture allowance. The results showed that PMRH cows consumed approximately $5 \mathrm{~kg}$ of DM pasture/d more than cows fed according to the other strategies with a lower pasture allowance. The PMRH cows also produced more ECM than all the other groups at all amounts of supplement offered. Thus the fourth hypothesis is accepted.

It is important to note that high pasture allowances of $28 \mathrm{~kg}$ of $\mathrm{DM} / \mathrm{cow}$ per $\mathrm{d}$, such as were offered to PMRH cows, would not be offered on commercial dairy farms when cows were also receiving such high amounts of supplements. Pasture allowances of this magnitude were offered as an experimental treatment to assess how much extra pasture the cows would consume when pasture availability was not limiting. The high postgrazing pasture masses and low pasture utilization for cows on PMRH feeding strategy indicate a high amount of wasted pasture and reduced pasture quality as the sward regrows (Holmes et al., 2002). Further research is needed to determine the optimum pasture allowance in these feeding systems for a given amount of supplement offered, while minimizing pasture wastage and maximizing pasture quality.

Cows fed according to the FGM, PMRL, and PMRH strategies also consumed more supplement than control 
cows at the greater amounts of supplement offered. For example, PMRL cows ate $0.7 \mathrm{~kg}$ of DM/cow per d more supplement than control cows when the nominal rate of $14 \mathrm{~kg}$ of DM/cow per d of total supplement was offered. As a consequence of greater intake of both pasture and supplement, PMRL cows offered the nominal rate of $14 \mathrm{~kg}$ of $\mathrm{DM} /$ cow per d of PMR ingested a combined total of 18.7 MJ of estimated ME/cow per d more than control cows offered the same level of supplement.

It is likely that the increased total DMI and ECM yield of the FGM, PMRL, and PMRH cows compared with the control cows was driven, at least in part, by the presence of canola meal in those diets, and the correspondingly higher concentrations of dietary CP. Protein supplements such as soybean meal and canola meal have previously been associated with increased DMI (Butler, 1998; Broderick, 2003; Ipharraguerre and Clark, 2005; Olmos Colmenero and Broderick, 2006) via a variety of mechanisms. One possibility is that higher protein feeds have greater buffering capacity in the rumen than lower protein feeds (Allen et al., 2006), thus acting to stabilize ruminal fluid $\mathrm{pH}$ to a relatively greater degree and, in turn, leading to a greater inclination to eat.

An additional mode of action for the increased DMI and subsequent ECM yield of PMR and FGM cows, compared with control cows, may be that the additional CP provided by the canola meal resulted in an increased, and more balanced, supply of amino acids, which enhanced milk production and, as a result of the increased energy demand, increased DMI (pull effect; Huhtanen et al., 2011).

The reduced pasture intake of cows offered the high amounts of control diet compared with PMR and FGM cows may also be partly explained by the differences in starch type. Several experiments have shown decreased intake by lactating cows on barley versus corn-based TMR (McCarthy et al., 1989; Casper and Schingoethe, 1989; Casper et al., 1999; Bengochea et al., 2005), due presumably to coincident reductions in fiber digestibility (Khorasani et al., 2001).

The inclusion of corn grain on the FGM, PMRL, and PMRH diets is also likely to be a contributing factor to the increased ECM in cows fed according to those strategies, compared with the control cows. Corn grain, because it is a more slowly digestible starch source than wheat grain, can mitigate inefficiencies in rumen fermentation induced by lower and fluctuating rumen $\mathrm{pH}$. In a tightly controlled experiment using cows individually fed PMR in metabolism stalls, Greenwood et al. (2014) reported that cows fed a corn-based PMR had higher ruminal and less variable ruminal fluid $\mathrm{pH}$ than control cows, but this was not observed in the current experiment in which only one cow in some experimental units of 6 cows was fitted with a rumen fistula. Greenwood et al. (2014) did not report any differences in whole tract digestibility of the 2 diets, in spite of these differences in ruminal fluid $\mathrm{pH}$.

The improved ECM production responses of PMR and FGM cows compared with control cows were associated with milk fat concentrations not declining to the same extent with increasing supplement intake as they did for the control. This was also reported by Auldist et al. (2013, 2014). The mechanisms involved in such reductions in milk fat concentration cows are not fully understood; however, diet is a major factor (Bauman and Griinari, 2003; Shingfield et al., 2010). Diets with low fiber and high starch or lipids rich in PUFA are often associated with milk fat depression (Stockdale et al., 1987). These types of diets are coincident with low ruminal fluid $\mathrm{pH}$ that cause a shift in the microbial population in the rumen and altered rumen lipid metabolism, leading to an increase in the amount of specific biohydrogenation intermediaries that have anti-lipogenic effects (Bauman and Griinari, 2003). In diets other than the control, approximately half of the starch from wheat was replaced with corn grain starch, leading to potential differences in site and end products of digestion (Khorasani et al., 2001). Given the lipogenic roles of acetate and butyrate and the glucogenic role of propionate (Sutton, 1984), previous studies have shown that milk fat reduction is commonly associated with a decline in the ruminal $(\mathrm{A}+\mathrm{B}) / \mathrm{P}$ ratio, as was observed for all groups as supplement intake increased, but which was numerically greater in the control cows than cows offered the other supplements.

There were also differences in the yield and concentrations of milk protein between groups, with control cows having the lowest concentrations and yields of milk protein and PMRH cows the greatest, with PMRL and FGM cows intermediate. Increased milk protein concentrations in response to increasing intakes of DM and ME have been reported previously (Auldist et al., 2000), and are an important consideration in assessing the economic viability of PMR strategies given the usefulness of milk protein for manufacturing purposes (Dalgleish, 1993) and the fact that many Australian dairy producers are paid more than double for protein than they are for fat (Dairy Australia, 2015).

It has been hypothesized previously (Auldist et al., 2013) that feeding the same amounts of DM (and estimated ME) as a PMR on a feed pad, as opposed to feeding it using the traditional control strategy, could also improve milk production responses by increasing the time taken to ingest the grain and thereby mitigating the severity of the variations and decline in ru- 
men pH. However, Auldist et al. (2013) and Wright et al. (2014) rejected this possibility after showing no response when the components of the diet were left the same and only the form of the diet was altered (i.e., changing from a traditional diet of grain fed in the parlor to a simple PMR comprising cereal grain and pasture silage). This is consistent with results from the current experiment in which cows fed according to the FGM and PMRL strategies, which contained the same dietary components but presented in a different form, produced the same amount of milk.

\section{CONCLUSIONS}

This experiment showed that when high amounts of supplements were fed to dairy cows grazing a restricted pasture allowance in early lactation, ECM production was greater when the supplements were fed as a PMR containing corn grain and canola meal, compared with feeding the same amount of $\mathrm{ME}$ as wheat grain in the milking parlor and alfalfa hay in the paddock. When the grain components of the PMR were mixed and fed in the parlor at milking, with the forage component fed in the paddock, the same ECM yield was achieved. In cows fed PMR while also offered a high pasture allowance, pasture intake was further increased, with a coincident increase in milk production, although this resulted in higher postgrazing pasture masses and reduced pasture utilization. Much of the increased response in cows fed according to the FGM and PMR strategies was associated with the arrested decline in milk fat concentrations as supplement intake increased, compared with the marked decline in milk fat concentrations observed in the control cows. These results have important practical implications in that they show the potential for increasing milk production by carefully considering the composition of supplements offered to grazing cows. It was also shown that the dietary grain components could be delivered using existing feeding infrastructure in the parlor: this makes these feeding strategies relevant to a greater number of farmers in the pasture-based dairy industries of Australia and elsewhere, the majority of whom do not have feed pads or mixer wagons.

\section{ACKNOWLEDGMENTS}

The authors are grateful to G. Morris, A. McDonald, D. Mapleson, T. Phillips, C. Macleod, T. Hookey, S. Ziero, L. Dorling (all of DEDJTR Ellinbank), and DEDJTR Ellinbank farm staff for cow feeding and husbandry. Thanks also go to Dairy Australia's Nutrition Advisory Group (Melbourne, Australia) for support with the design and interpretation of this experiment.
This research was funded by DEDJTR and Dairy Australia (Melbourne, Australia).

\section{REFERENCES}

Allen, M. S., J. A. Voelker, and M. Oba. 2006. Physically effective fibre and regulation of ruminal $\mathrm{pH}$ : More than just chewing. Pages 270-278 in Production Diseases in Farm Animals. N. P. Joshi and T. H. Herdt, ed. Wageningen Academic Publishers, Wageningen, the Netherlands.

AOAC International. 2000. Official methods of analysis of AOAC International. 17th ed. AOAC International, Gaithersburg, MD.

Auldist, M. J., L. C. Marett, J. S. Greenwood, M. Hannah, J. L. Jacobs, and W. J. Wales. 2013. Effects of different strategies for feeding supplements on milk production responses in cows grazing a restricted pasture allowance. J. Dairy Sci. 96:1218-1231.

Auldist, M. J., L. C. Marett, J. S. Greenwood, M. M. Wright, M. Hannah, J. L. Jacobs, and W. J. Wales. 2014. Replacing wheat with canola meal in a partial mixed ration increases the milk production of cows grazing at a restricted pasture allowance in spring. Anim. Prod. Sci. 54:869-878.

Auldist, M. J., N. A. Thomson, T. R. Mackle, J. P. Hill, and C. G. Prosser. 2000. Effects of pasture allowance on the yield and composition of milk from cows of different $\beta$-lactoglobulin phenotypes. J. Dairy Sci. 83:2069-2074.

Baird, D. B. 1994. The design of experiments with covariates. PhD Thesis. University of Otago, New Zealand.

Bargo, F., L. D. Muller, G. A. Varga, J. E. Delahoy, and T. W. Cassidy. 2002. Ruminal digestion and fermentation of high-producing dairy cows with three different feeding systems combining pasture and total mixed rations. J. Dairy Sci. 85:2964-2973.

Bauman, D. E., and J. M. Griinari. 2003. Nutritional regulation of milk fat synthesis. Annu. Rev. Nutr. 23:203-227.

Bengochea, W. L., G. P. Lardy, M. L. Bauer, and S. A. Soto-Navarro. 2005. Effect of grain processing degree on intake, digestion, ruminal fermentation, and performance characteristics of steers fed medium-concentrate growing diets. J. Anim. Sci. 83:2815-2825.

Broderick, G. A. 2003. Effects of varying dietary protein and energy levels on the production of lactating dairy cows. J. Dairy Sci. 86:1370-1381.

Butler, W. R. 1998. Review: Effect of protein nutrition on ovarian and uterine physiology in dairy cattle. J. Dairy Sci. 81:2533-2539.

Casper, D. P., H. A. Maiga, M. J. Brouk, and D. J. Schingoethe. 1999. Synchronization of carbohydrate and protein sources on fermentation and passage rates in dairy cows. J. Dairy Sci. 82:1779-1790.

Casper, D. P., and D. J. Schingoethe. 1989. Lactational response of dairy cows to diets varying in ruminal solubilities of carbohydrate and crude protein. J. Dairy Sci. 72:928-941.

Dalgleish, D. G. 1993. Bovine milk protein properties and the manufacturing quality of milk. Livest. Prod. Sci. 34:75-93.

Dixon, R. M., and C. R. Stockdale. 1999. Associative effects between forages and grains: Consequences for feed utilization. Aust. J. Agric. Res. 50:757-773.

Doyle, P. T., S. A. Francis, and C. R. Stockdale. 2005. Associative effects between feeds when concentrate supplements are fed to grazing dairy cows: A review of likely impacts on metabolisable energy supply. Aust. J. Agric. Res. 56:1315-1329.

Doyle, P. T., A. R. Lawson, C. R. Stockdale, and D. C. Cohen. 2000. Pasture for dairy production in Victoria, 2nd ed. Department of Natural Resources and Environment, Kyabram, Australia.

Doyle, P. T., C. R. Stockdale, W. J. Wales, G. P. Walker, and J. W. Heard. 2001. Limits to, and optimising of, milk production and composition from pastures. Recent Adv. Anim. Nutr. Aust. 13:9-18.

Doyle, P. T., and C. R. Stockdale. 2011. Dairy farm management systems: Seasonal, pasture-based, dairy cow breeds. Pages $29-37$ in Encyclopedia of Dairy Sciences. 2nd ed. J. W. Fuquay, P. F. Fox, and P. L. H. McSweeney, ed. Vol 2. Academic Press, Amsterdam, the Netherlands. 
Earle, D. 1976. A guide to scoring dairy cow condition. J. Agric. Vic. $74: 228-231$.

Earle, D. F., and A. A. McGowan. 1979. Evaluation and calibration of an automated rising plate meter for estimating dry matter yield of pasture. Aust. J. Exp. Agric. Anim. Husb. 19:337-342.

Greenwood, J. S., M. J. Auldist, L. C. Marett, M. C. Hannah, J. L. Jacobs, and W. J. Wales. 2014. Ruminal pH and whole-tract digestibility in dairy cows consuming fresh cut herbage plus concentrates and conserved forage fed either separately or as a partial mixed ration. Anim. Prod. Sci. 54:1056-1063.

Holmes, C. W., I. M. Brookes, D. J. Garrick, D. D. S. Mackenzie, T. J. Parkinson, and G. F. Wilson. 2002. Milk production from pasture. D. Swain, ed. Massey University, Palmerston North, New Zealand.

Huhtanen, P., M. Hetta, and C. Swensson. 2011. Evaluation of canola meal as a protein supplement for dairy cows: A review and a metaanalysis. Can. J. Anim. Sci. 91:529-543.

Ipharraguerre, I. R., and J. H. Clark. 2005. Varying protein and starch in the diet of dairy cows. II. Effects on performance and nitrogen utilization for milk production. J. Dairy Sci. 88:2556-2570.

Kellaway, R., and T. Harrington. 2004. Feeding Concentrates: Supplements for Dairy Cows. Rev. ed. Landlinks Press, Collingwood, Victoria, Australia.

Khorasani, G. R., E. K. Okine, and J. J. Kennelly. 2001. Effects of substituting barley grain with corn on ruminal fermentation characteristics, milk yield, and milk composition of Holstein cows. J. Dairy Sci. 84:2760-2769.

Leddin, C. M., C. R. Stockdale, J. Hill, J. W. Heard, and P. T. Doyle. 2009. Increasing amounts of crushed wheat fed with pasture hay reduced dietary fiber digestibility in lactating dairy cows. J. Dairy Sci. 92:2747-2757.

Leddin, C. M., C. R. Stockdale, J. Hill, J. W. Heard, and P. T. Doyle. 2010. Increasing amounts of crushed wheat fed with Persian clover herbage reduced ruminal $\mathrm{pH}$ and dietary fibre digestibility in lactating dairy cows. Anim. Prod. Sci. 50:837-846.

McCarthy, R. D., T. H. Klusmeyer, J. L. Vicini, and J. H. Clark. 1989. Effects of source of protein and carbohydrate on ruminal fermentation and passage of nutrients to the small intestine of lactating cows. J. Dairy Sci. 72:2002-2016.

Mould, F. L., E. R. Ørskov, and S. O. Mann. 1983. Associative effects of mixed feeds. I. Effects of type and level of supplementation and the influence of the rumen fluid $\mathrm{pH}$ on cellulolysis in vivo and dry matter digestion of various roughages. Anim. Feed Sci. Technol. 10:15-30.

National Health and Medical Research Council. 2004. Australian Code of Practice for the Care and Use of Animals for Scientific Purposes, 7th ed. Australian Government, Canberra, Australia.
NRC. 2001. Nutrient Requirements of Dairy Cattle. National Academy Press, Washington, DC.

Olmos Colmenero, J. J., and G. A. Broderick. 2006. Effect of dietary crude protein concentration on milk production and nitrogen utilization in lactating dairy cows. J. Dairy Sci. 89:1704-1712.

Shingfield, K. J., L. Bernard, C. Leroux, and Y. Chilliard. 2010. Role of trans fatty acids in the nutritional regulation of mammary lipogenesis in ruminants. Animal 4:1140-1166.

Stockdale, C. R., A. Callaghan, and T. E. Trigg. 1987. Feeding high energy supplements to pasture-fed dairy cows, effects of stage of lactation and level of supplement. Aust. J. Agric. Res. 38:927-940.

Sutton, J. D. 1984. Feeding and milk fat production. Pages $43-52$ in Milk Compositional Quality and its Importance in Future Markets. Occas. Publ. 9. Br. Soc. Anim. Prod., Edinburgh, UK.

Tyrrell, H. F., and J. T. Reid. 1965. Prediction of energy value of cow's milk. J. Dairy Sci. 48:1215-1223.

Vibart, R. E., V. Fellner, J. C. Burns, G. B. Huntington, and J. T. Green. 2008. Performance of lactating dairy cows fed varying levels of total mixed ration and pasture. J. Dairy Res. 75:471-480.

Wales, W. J., D. W. Dellow, P. T. Doyle, and A. R. Egan. 2000. Effects of feeding additional pasture hay in autumn to dairy cows grazing irrigated perennial ryegrass-white clover pasture and supplemented with barley grain. Aust. J. Exp. Agric. 40:1-9.

Wales, W. J., and P. T. Doyle. 2003. Effect of grain and straw supplementation on marginal milk production responses and rumen function of cows grazing highly digestible subterranean clover pasture. Aust. J. Exp. Agric. 43:467-474.

Wales, W. J., L. C. Marett, J. S. Greenwood, M. M. Wright, J. B. Thornhill, J. L. Jacobs, C. K. M. Ho, and M. J. Auldist. 2013. Use of partial mixed rations in pasture-based dairying in temperate regions of Australia. Anim. Prod. Sci. 53:1167-1178.

Walker, G. P., C. R. Stockdale, W. J. Wales, P. T. Doyle, and D. W. Dellow. 2001. Effect of level of grain supplementation on milk production responses of dairy cows in mid-late lactation when grazing irrigated pastures high in paspalum (Paspalum dilatatum Poir.). Aust. J. Exp. Agric. 41:1-11.

Wright, M. M., L. C. Marett, J. S. Greenwood, M. Hannah, J. L. Jacobs, W. J. Wales, and M. J. Auldist. 2014. Feeding a partial mixed ration once a day did not increase milk production compared with feeding grain in the dairy and forage in the paddock. Anim. Prod. Sci. 54:1405-1411. 